\title{
CAN LEGISLATIVE REFORM SECURE REWARDS FOR AUTHORS? EXPLORING OPTIONS FOR THE NEW ZEALAND COPYRIGHT ACT
}

\author{
Lucy Elizabeth Kenner*
}

\begin{abstract}
Copyright law protects works, but not the authors who create them. As the weaker party in negotiations, authors face insufficiently remunerative bargains, often made early in their careers. The Copyright Act 1994 is currently under review, and reform should be considered. This article explores legislative mechanisms to secure rewards for authors from their works. It considers the contrasting schemes in the United States and in Germany and evaluates the desirability of adopting these approaches in New Zealand. The United States approach is a termination right that allows authors to recapture their copyrights after 35 years. The scheme in Germany requires that authors' contracts meet minimum equitable standards or be subject to amendment. This article considers that there are significant problems with adopting either approach in New Zealand. These include the risk of harming authors overall, enforcement, the interests of disseminators, arbitrariness, uncertainty and administrative difficulties. This article recommends that neither option is desirable. It concludes that while there is a clear need for solutions, a cautious approach must be taken to any reforms which are intended to address such a complex problem.
\end{abstract}

\section{INTRODUCTION}

We signed a publishing agreement as unsuspecting teenagers, over three decades ago, when just starting out and when we knew no better - Nick Rhodes, Duran Duran. ${ }^{1}$

In 1980, five young British musicians sold the rights to exploit their works to Gloucester Place Music, owned by United States company Sony/ATV. The contracts were not unusual. In exchange

* Submitted as part of the LLB (Hons) programme at Victoria University of Wellington. I am grateful to my supervisor, Professor Graeme Austin, for his invaluable guidance and support. I would also like to thank the anonymous reviewer for helpful comments and advice.

1 Nicola Harley "Duran Duran lose High Court battle over US song rights in copyright test case" The Telegraph (online ed, United Kingdom, 2 December 2016). 
for assigning their worldwide copyrights to all future works made during the term of the contracts, they would each receive an advance and royalties. ${ }^{2}$ Those musicians were Duran Duran. The band soared to pop stardom, producing international hits "Hungry Like the Wolf" and "Girls on Film". Under the contracts, 37 of their most popular songs were automatically assigned to Gloucester Place Music, and their proceeds predetermined. ${ }^{3}$ Over three decades later, they sought to be released from their contracts, or at least, a chance to revise the deal. Had United States copyright law applied, they would have been able to recapture the right to exploit their songs in the United States under the United States termination right. ${ }^{4}$ This would have allowed the band to renegotiate a substantially better deal for the exploitation of their copyrights in the United States - the most lucrative market for their works. Instead, an English court's interpretation of the contracts left Duran Duran empty-handed, tied to the original bargain. ${ }^{5}$

Authors are central to the legitimacy of copyright. ${ }^{6}$ While copyright in a work originally vests in the author, ${ }^{7}$ he or she will typically assign or licence the rights to an intermediary (such as a publisher), which will disseminate the work to the public. ${ }^{8}$ These intermediaries will be referred to in this article as "disseminators". The transfer of rights can be forever. ${ }^{9}$ Thus copyright protection is not synonymous with providing rewards to authors, as it is not necessarily authors' interests that are protected. $^{10}$

When copyright contracts are formed, stronger parties may negotiate on more favourable terms. ${ }^{11}$ Creative industries are typically characterised by a large number of aspiring authors, and a small number of disseminators. ${ }^{12}$ Combined with the fact that powerful corporations hold extensive market

2 Gloucester Place Music Ltd v Le Bon [2016] EWHC 3091 (Ch) at [2].

3 At [3].

417 USC $\$ 203$.

5 Gloucester Place Music Ltd v Le Bon, above n 2, at [44].

6 See IceTV Pty Ltd v Nine Network Australia Pty Ltd [2009] HCA 14, [2009] CLR 458 at 470 where the High Court of Australia stated: "The 'author' of a literary work and the concept of 'authorship' are central to the statutory protection given by copyright legislation, including the [Australian] Act."

7 Copyright Act 1994, s 21(1).

8 Colin Golvan Copyright Law and Practice (The Federation Press, Sydney, 2007) at 217.

9 The copyright in most works lasts for the life of the author plus 50 years: Copyright Act, s 22(1).

10 Jane Ginsburg "How Copyright Law Got a Bad Name For Itself" (2002) 26 Colum J L \& Arts 61 at 62.

11 Giuseppina D'Agostino Copyright, Contracts, Creators: New Media, New Rules (Edward Elgar Publishing, Cheltenham, 2010) at 113.

12 William Patry How to Fix Copyright (Oxford University Press, New York, 2011) at 29. 
information unavailable to authors, ${ }^{13}$ such as valuations for similar works and market demand, authors are placed in a weak bargaining position from the outset. ${ }^{14}$

It is also virtually impossible to predict whether an author's work will be successful until it has been exploited, which typically occurs only after contracting. ${ }^{15}$ If the work becomes particularly lucrative, the initial bargain will no longer reflect its true value. This will be referred to in this article as the "prediction problem".

These problems have not gone unnoticed. Copyright has been criticised by commentators for not protecting the paramount interests of authors. ${ }^{16} \mathrm{~A}$ handful of countries have responded by taking legislative measures to protect authors' rewards, not just their works. Such measures include restricting lump sum buyouts, ${ }^{17}$ declaring onerous terms in copyright contracts void, ${ }^{18}$ and the opportunity for authors to recapture their copyrights after a number of years. ${ }^{19}$ These will be called "re-evaluation mechanisms" in this article, as they seek to "re-evaluate" authors' bargains on more lucrative terms.

The New Zealand Copyright Act 1994 is currently under review. ${ }^{20}$ In light of overseas responses to the problems just identified, adopting a re-evaluation mechanism deserves serious consideration. This article explores whether, and if so how, such a scheme should be adopted. It has three substantive parts. Part II describes the current position in New Zealand and argues that there are solid historical foundations for reform. Part III sets out two contrasting systems: termination of transfers in the United States and the regulation of authors' contracts in Germany. I provide an evaluation of these schemes in Part IV.

13 Ruth Towse "Copyright Policy, Cultural Policy and Support for Artists" in Wendy Gordon and Richard Watt (eds) The Economics of Copyright: Developments in Research and Analysis (Edward Elgar Publishing, Cheltenham, 2003) 66 at 69.

14 Golvan, above n 8, at 218-219.

15 Kate Darling "Contracting About the Future: Copyright and New Media" (2012) 10 NJTIP 485 at 513.

16 See Jane Ginsburg "The Concept of Authorship in Comparative Copyright Law" (2003) 52 DePaul L Rev 1063 at 1065 .

17 Code de la Propriété Intellectuelle 1992 (France), arts L131-4, L132-5-L132-6 (translation: Intellectual Property Code).

18 Auteurswet 1912 (Netherlands), s 25f (translation: Copyright Act).

1917 USC $\$ \$ 203$ and 304(c).

20 Ministry of Business, Innovation and Employment Review of the Copyright Act 1994: Terms of Reference (2017). 
Insofar as providing an income to authors remains a justification for copyright, re-evaluation mechanisms are fundamentally worthwhile. ${ }^{21}$ However, on closer analysis there are real obstacles in the way of reform. As I argue below, termination rights benefit bestselling authors without addressing structural inequality or balancing the interests of disseminators. While regulating copyright contracts is appealing in theory, in practice authors are unlikely to enforce their rights under such a scheme, and there are further difficulties with uncertainty and administration. If one or both of these options is proposed in New Zealand, I conclude that neither one should be adopted.

New Zealand is a net importer of copyright works. ${ }^{22}$ Assuming that a re-evaluation mechanism applies to all authors, any benefits that result from adopting these schemes will predominantly accrue overseas. Accordingly, the case for reform in New Zealand should be particularly compelling. As I conclude, it is not.

\section{SETTING THE SCENE IN NEW ZEALAND}

\section{A The Current Position}

\section{The Copyright Act 1994}

The New Zealand Copyright Act does not contain a re-evaluation mechanism. ${ }^{23}$ As in other Common Law countries, the copyright in a work is easily assigned. ${ }^{24}$ Almost invariably, contracts assigning the copyright entirely or granting a licence to exploit the works will be upheld. ${ }^{25}$

\section{Unconscionable bargain and restraint of trade}

Even so, there may be some doctrines of contract or common law that might offer authors some relief. In theory, an author could invoke the unconscionable bargain doctrine. ${ }^{26}$ However, because an inequality of bargaining power alone is insufficient to establish unconscionability, courts in New

21 Rebecca Giblin "Reimagining Copyright's Duration" in Rebecca Giblin and Kimberlee Weatherall (eds) What if We Could Reimagine Copyright? (ANU Press, Acton, 2017) 177 at 192.

22 Stephanie Woods "Creative Commons: A Useful Development in the New Zealand Creative Sphere?" (2008) 14 Canta L Rev 31 at 35.

23 The artist's right to receive additional proceeds whenever his or her artwork is resold and equitable remuneration for performers have been considered but rejected: Ministry of Economic Development Performers' Rights (Discussion Paper, July 2001); and Ministry for Cultural Heritage A Resale Royalty Right for Visual Artists: Options for its Possible Application to New Zealand (Discussion Paper, April 2007).

24 Subject to the requirement that an assignment of copyright is not effective unless in writing signed by or on behalf of the assignor: Copyright Act, s 114. This is subject to the possibility of an assignment in equity. See for example Brooker v John Friend Ltd [1936] NZLR 743 (SC) at 749.

25 Lionel Bently and Brad Sherman Intellectual Property Law (4th ed, Oxford University Press, Oxford, 2014) at 319 .

26 Rick Bigwood Exploitative Contracts (Oxford University Press, New York, 2003) at 231. 
Zealand are unlikely to intervene in absence of striking facts with a particularly immoral flavour. ${ }^{27}$ Thus if the author's rewards are consistent with industry norms, the unconscionable bargain doctrine will rarely release the author from the contract. Furthermore, as unconscionable conduct is assessed at the time of contracting, the doctrine is not equipped to deal with the problem that copyright contracts typically appear unfair only with hindsight. ${ }^{28}$ While in retrospect Duran Duran's royalty split may seem inadequate based on their later success, the validity of the contracts was never doubted. As such, while the unconscionable bargain doctrine will occasionally offer some solutions for authors, it does not provide a substitute for a re-evaluation mechanism.

The restraint of trade doctrine may provide redress for some authors. For example, in Schroeder Music Publishing Co Ltd v Macaulay the House of Lords applied restraint of trade principles to a standard form contract entered into between an unknown 21-year-old songwriter and a music publisher. ${ }^{29}$ The contract purported to assign the copyrights for the whole world. ${ }^{30}$ The publisher could terminate the arrangement at will by giving just one month's notice. The artist had no such termination right. Schroeder Music was not obliged to publish the songs at all, and if it elected not to do so, the artist would not be paid nor could he regain his copyrights. ${ }^{31}$ Applying restraint of trade principles, the Court found the contract to be unenforceable. ${ }^{32}$

In New Zealand, the Contract and Commercial Law Act 2017 seems to give an approving nod in the direction of the restraint of trade doctrine. Section 83 of the Act allows the court to delete or modify a provision that constitutes an unreasonable restraint of trade, or to decline to enforce a contract where deletion or modification would unreasonably alter the bargain between the parties. In the context of athletes' contracts, one Australian commentator has suggested that a flexible approach to restraint of trade on public policy grounds in unique industries such as the sporting industry may be desirable, noting Schroeder as an example of where the Court placed weight on the inequality of bargaining power between the parties. ${ }^{33}$ Given the inequality of bargaining power in creative industries and the prediction problem, there may be greater scope for the doctrine to re-evaluate

27 Gustav and Co Ltd v Macfield Ltd [2007] NZCA 205 at [47].

28 The Court of Appeal listed non-exhaustive principles on the unconscionable bargain doctrine that were approved by the Supreme Court on appeal. The Supreme Court reversed the Court of Appeal's judgment on the basis that conduct must be assessed at the time of contracting: Gustav and Co Ltd v Macfield Ltd [2008] NZSC 47, [2008] 2 NZLR 735 at [5].

29 Schroeder Music Publishing Co Ltd v Macaulay [1974] 1 WLR 1308 (HL).

30 At 1310.

31 At 1313-1314.

32 At 1315.

33 David Thorpe "The Use of Multiple Restraints of Trade in Sport and the Question of Reasonableness" (2017) 7 Australian and New Zealand Sports Law Journal 63 at 77. 
authors' contracts for policy reasons. While this scope would be more limited than a re-evaluation mechanism, given the conclusion of this article, a more tailored restraint of trade doctrine could be preferable for a jurisdiction where freedom of contract is highly valued.

\section{B The Background to Reform}

In light of New Zealand's copyright history, adopting a re-evaluation mechanism might be considered a viable policy option in the context of the New Zealand Copyright Act review. Domestic policymakers should not be deterred from considering such reforms by the recurring story that "copyright" in the United Kingdom tradition, which New Zealand follows, is less concerned with the author than civil law "authors' rights" jurisdictions. ${ }^{34}$ The fundamental concept of protecting authors' rewards in fact dates back to the very first copyright legislation, the Statute of Anne 1710 (Eng). ${ }^{35}$ Although the Act has been viewed as predominantly a publishers' instrument, there was an important exception. ${ }^{36}$ If authors remained living 14 years after creating their works, the sole right of printing or disposing of copies would return to them for a further 14 years, even if they had previously transferred these rights to a publisher. ${ }^{37}$ In theory, this provided authors with greater control over their works. ${ }^{38}$ While there is little legislative history on the provision, its purpose appears to have been to address the weak bargaining position of authors and the prediction problem. ${ }^{39}$

This feature of the Statute of Anne was not re-enacted in the Imperial Copyright Act of 1911. Instead, the 1911 Act provided that 25 years after the author's death any copyright grant would revert to his or her heirs. ${ }^{40}$ Two years later, New Zealand followed suit and enacted the Copyright Act 1913, which substantially resembled its United Kingdom equivalent and also contained such a reversionary

34 Silke von Lewinski International Copyright Law and Policy (Oxford University Press, New York, 2008) at 41.

35 Statute of Anne 1710 (Eng) 8 Ann c 21 .

36 David Saunders "Dropping the Subject: An Argument for a Positive History of Authorship and the Law of Copyright" in Brad Sherman and Alain Strowel (eds) Of Authors and Origins: Essays on Copyright Law (Oxford University Press, New York, 1994) 93 at 94.

37 Statute of Anne, s 11.

38 Lionel Bently and Jane Ginsburg "'The Sole Right ... Shall Return to the Authors': Anglo-American Authors' Reversion Rights from the Statute of Anne to Contemporary U.S. Copyright" (2010) 25 Berkeley Tech LJ 1475 at 1485

39 D'Agostino, above n 11, at 116; and Oren Bracha "The Adventures of the Statute of Anne in the Land of Unlimited Possibilities: The Life of a Legal Transplant" (2010) 25 Berkeley Tech LJ 1427 at 1438.

40 Copyright Act 1911 (UK), s 5(2). See Redwood Music Ltd v Francis Day \& Hunter Ltd [1981] RPC 337 (HL) at 344 where Lord Salmond agreed with the Court of Appeal that the "object of the proviso was to safeguard authors and their heirs from the consequences of any imprudent disposition which authors might make of the fruits of their talent and originality". 
provision. ${ }^{41}$ While in reality these provisions did nothing to benefit authors, as the reversion of copyright occurred only after their deaths, the objective of policymakers appears to have been to offer some protection from authors' bad bargains, with the benefits falling to their estates. ${ }^{42}$

Neither the New Zealand nor the United Kingdom Act currently contains a reversionary provision, ${ }^{43}$ implying that, in this context at least, copyright law in the United Kingdom tradition is less concerned with the author than it once was. ${ }^{44}$ Adopting a re-evaluation mechanism would certainly be a notable departure from the status quo of protecting authors' works, but not their incomes. Nevertheless, such a scheme would not be entirely foreign to copyright law in New Zealand. Combined with the weak bargaining position of authors and the prediction problem, this establishes a solid foundation for considering a re-evaluation mechanism in the New Zealand Copyright Act review.

\section{POSSIBILITIES FOR REFORM}

The United States termination right and the regulation of authors' contracts in Germany are two of the most prominent re-evaluation mechanisms. I have chosen to evaluate these schemes as they offer fundamentally different options for domestic policymakers to consider.

\section{A The United States Termination Right}

The United States Copyright Act provides authors with a termination right. ${ }^{45}$ It is the only country to have such a right in its copyright law. Authors or their statutory heirs may terminate their copyright grants after 35 years by serving the grantee notice of their intention to exercise the right. If the grant covers the right of publication, the grant can either be terminated 35 years after publication or 40 years after executing the grant, whichever occurs earlier. ${ }^{46}$ From the start of the relevant period, authors have a five-year window in which they must exercise their termination rights. At the date of termination, all rights covered by the grants will revert to the author. ${ }^{47}$ Essentially, authors can get their rights back after three decades of signing them away.

41 Copyright Act 1913, s 8(2).

42 See Paul Torremans and Carmen Otero García-Castrillón "Reversionary Copyright: A Ghost of the Past or a Current Trap to Assignments of Copyright?" (2012) 2 IPQ 77 at 78 stating that the "clear objective" was protecting authors and their heirs, but that a "reversionary copyright 25 years after the death of the author does little to protect the author and his or her heirs from imprudent assignments, and lets their effects continue and do harm until 25 years after the death of the author".

43 Copyright, Designs and Patents Act 1988 (UK).

44 D'Agostino, above n 11, at 114.

4517 USC $\$ 203$.

$46 \S 203(\mathrm{a})(3)$.

$47 \S 203$ (b). 
The termination right cannot be waived in advance, ${ }^{48}$ representing a notable author-centric departure from the freedom of contract that is typically at the forefront of United States copyright law. ${ }^{49}$ This is crucial for any functional re-evaluation mechanism. Due to an inequality of bargaining power, authors will presumably be made to forfeit any re-evaluation rights that may be waived in advance. ${ }^{50}$ Following a United States Supreme Court ruling that authors could effectively waive a provision in the Copyright Act 1909 that was intended to protect their interests, ${ }^{51}$ this was precisely what occurred. ${ }^{52}$ The premise behind the provision was thus entirely frustrated. ${ }^{53}$

Commentators have assumed that the termination right applies to non-United States authors on the basis that international copyright law requires that countries grant foreign and domestic authors the same substantive rights. ${ }^{54}$ The right applies only to United States copyrights - that is, the right to exploit the copyright in the United States. While Duran Duran was granted leave to appeal in February 2017, no date has yet been determined for the hearing. Should an appeal be successful, the band members will reclaim their copyrights within the United States. However, Gloucester Place Music will retain the right to exploit the songs elsewhere. ${ }^{55}$

$48 \S 203(a)(5)$.

49 See Deborah Bouchoux Intellectual Property: The Law of Trademarks, Copyrights, Patents and Trade Secrets (5th ed, Cengage Learning, Boston, 2016) at 24 where it is argued that the termination right in the United States Copyright Act is highly unusual and contrary to the general principles of contract law that once a contract has been validly entered into, the parties must abide by its terms.

50 Anthony Reese "Reflections on the Intellectual Commons: Two Perspectives on Copyright Duration and Reversion" (1995) 47 Stan L Rev 707 at 734.

51 Fisher Music Co v M Witmark \& Sons 318 US 643 (1943) at 656-657. In the United States, copyright was previously granted for two consecutive 28-year terms. Copyright for the second term was obtained only if renewed by the author or the heirs: Copyright Act 1909 (US), s 24.

52 Suzanne Anderson "Bleak House Revisited: An Appraisal of the Termination Provisions of the 1976 Copyright Act - Sections 203 and 304(c)" (1986) 65 Or L Rev 829 at 837.

53 Marc S Brown "Copyright Law - Termination of Transfers; Trump Card or Joker?" (1994) 1 Det C L Ent \& Sports L F 41 at 52; Adam Rich "Finding the Groove: A Path Forward on Termination of Sound Recording Transfers" (2013) 57 N Y L Sch L Rev 363 at 367; and Daniel Gould "Time's Up: Copyright Termination, Work-For-Hire and the Recording Industry" (2007) 31 Colum J L \& Arts 91 at 101.

54 Jane C Ginsburg and Robert A Gorman Copyright Law (Foundation Press, New York, 2012) at 92. The principle of national treatment is contained in the Berne Convention for the Protection of Literary and Artistic Works 1161 UNTS 30 (opened for signature 9 September 1886, entered into force 24 April 1928) [Berne Convention], art 5; and Agreement on Trade-Related Aspects of Intellectual Property Rights (signed 15 April 1994, entered into force 1 January 1995) [TRIPS Agreement], art 3. As New Zealand is a signatory to both treaties proposed reforms would need to comply with these obligations.

55 Paul Goldstein and Bernt Hugenholtz International Copyright: Principles, Law, and Practice (3rd ed, Oxford University Press, New York, 2013) at 270; and Donald Passman All You Need to Know About the Music Business (9th ed, Simon \& Schuster, New York, 2015) at 357. 
Authors are precluded from entering into new agreements regarding their copyrights until after termination is effective. ${ }^{56}$ Importantly, the provision allows them to renegotiate with the original grantee or the grantee's successor, effectively offering these parties a right of "first refusal" to the copyrights. ${ }^{57}$ The most likely outcome will consequently be renegotiations between the original parties, and a revised deal on terms more lucrative for the author. ${ }^{58}$ Alternatively, authors may choose to contract with a different party, exploit the works themselves or republish them with a creative commons licence after regaining their copyrights. ${ }^{59}$

The United States termination right has not been without practical difficulties. ${ }^{60}$ For instance, a United States Court of Appeals for the Ninth Circuit ruling has undermined the purpose of termination rights. ${ }^{61}$ In that ruling, the Court held that the revoking and re-granting of an original licence circumvented the termination right, ${ }^{62}$ indicating that in some circumstances stronger parties will be able to sidestep the provision. ${ }^{63}$ The formalities required for authors to successfully recapture their copyrights are also dense, requiring authors to jump through several hoops if they wish to exercise their termination rights. ${ }^{64}$ If such a right is proposed in New Zealand, domestic policymakers will need to address these practical issues.

\section{B Regulating Copyright Contracts}

In 2002, the German Copyright Act was amended to provide authors with a set of interlocking provisions intended to secure fair payment under their contracts. ${ }^{65}$ Like the termination right, parties

5617 USC $\$ 203(b)(4)$.

57 HR Rep No 94-1476 at 127 (1976).

58 Naz Nazarinia Scott "2013: The Year of Terminations"" (2013) 14 U Denv Sports \& Ent LJ 45 at 57.

59 Amy Gilbert "The Time Has Come: A Proposed Revision to 17 U.S.C. § 203" (2016) 66 Case W Res L Rev 807 at 828 .

60 Pamela Samuelson "The Copyright Principles Project: Directions For Reform" (2010) 25 Berkeley Tech LJ 1175 at 1241 .

61 The decision concerned the termination right applying to pre-1978 works under 17 USC § 304(c).

62 Milne v Stephen Slesinger Inc 430 F 3d 1036 (9th Cir 2005) at 1042-1043.

63 See Sean Stopler "Termination Rights: An In-Depth Look at Looming Issues Under the Copyright Act of 1976" (2011) 13 Tex Rev Ent \& Sports L 33 at 47 noting the same outcome as Milne v Stephen Slesinger Inc in Penguin Group USA v Steinbeck 537 F 3d 193 (2nd Cir 2008) but the contrary ruling in Classic Media v Mewborn 532 F 3d 978 (9th Cir 2008).

64 Anthony Reese "Termination Formalities and Notice" (2016) 96 B U L Rev 895 at 898 . Authors must serve their termination notice not less than two and not more than ten years prior to recapturing their copyrights. The termination date must also be between 35 and 40 years after the original grant: 17 USC $\S ~ 203(a)(3)$ 203(a)(4)(A).

65 Urheberrechtsgesetz 1965 (Germany), ss 32, 32a and 36 (translation: Copyright Act) [German Copyright Act]. As of March 2017, additional reforms are also applicable that are not analysed in depth in this article. 
cannot contract out of these provisions. ${ }^{66}$ Under the German Act, authors now have the right to contractually agreed "equitable remuneration". ${ }^{67}$ If remuneration is not equitable, authors may require their contracting partners to modify their contracts to provide remuneration that is ${ }^{68}$ Remuneration will be considered "equitable" if it corresponds with what is "customary and fair" in business, or is determined in accordance with a joint remuneration agreement. ${ }^{69}$

The Act also specifically addresses the prediction problem through a provision commonly known as the "bestseller clause". ${ }^{70}$ Authors are entitled to require their contracts to be amended to provide "further equitable participation" if their remuneration is "conspicuously disproportionate" to the profitability of their works. ${ }^{71}$ Authors may also hold third parties who exploit the works accountable under the bestseller clause. ${ }^{72}$

Authors' associations and exploiters of copyright works may negotiate "joint remuneration agreements" to determine whether remuneration is equitable. ${ }^{73}$ The intention is to counteract structural inequality by nudging authors toward negotiating collectively, and to increase certainty by producing defined standards of acceptable remuneration. ${ }^{74}$ In reality, authors have tended not to form the suggested associations or to initiate negotiations, and very few joint agreements have been

These are the right to information and accountability under ss 32 and 32e, consequences for a breach of joint remuneration rules under ss $36 \mathrm{~b}-36 \mathrm{c}$, and the restriction of exclusive exploitation to a period of 10 years if the author has received a lump sum payment, with the ability to extend exclusivity to the full period after five years under s 40a.

66 German Copyright Act, ss 32(3) and 32a(3).

67 Section 32.

68 Section 32(1).

69 Section 32(2).

70 Martin Senftleben "Copyright, Creators and Society's Need For Autonomous Art - The Blessing and Curse of Monetary Incentives" in Rebecca Giblin and Kimberlee Weatherall (eds) What if We Could Reimagine Copyright? (ANU Press, Acton, 2017) 25 at 60.

71 German Copyright Act, 32a. Under s 32a(4) the bestseller clause does not apply to remuneration determined in accordance with a joint remuneration agreement.

72 Section $32 \mathrm{a}(2)$

73 Section 36(1). Under s 36(2) these associations must be representative, independent and empowered to make the agreements.

74 Karsten Gutsche "Equitable Remuneration for Authors in Germany - How the German Copyright Act Secures Their Rewards" (2003) 50 J Copyright Socy 257 at 268. 
reached. ${ }^{75}$ As this initiative has been relatively unsuccessful in Germany, there is no reason to expect it to thrive in New Zealand. ${ }^{76}$

The provisions apply to German authors and to nationals of European Union Member States and states in the European Economic Area. ${ }^{77}$ Whether they also apply to foreign authors remains unclear. ${ }^{78}$ Interestingly, when a termination right was proposed in Germany, it was quickly rejected. ${ }^{79}$

\section{EVALUATING OPTIONS FOR REFORM}

In this Part, I discuss whether a re-evaluation mechanism should be adopted in New Zealand, drawing on the United States and German schemes. There are significant problems with taking either approach. These problems include rewarding bestsellers at the expense of all others, harming disseminators, arbitrariness and uncertainty, and administrative difficulties that sprawl into the unknown. On balance, these obstacles outweigh the benefits of adopting either scheme in the New Zealand Copyright Act.

\section{A The Prediction Problem}

One purpose of re-evaluation mechanisms is to address the prediction problem. ${ }^{80}$ When bestselling authors have signed away their rights before knowing the value of their creative output, a termination right can provide the chance to renegotiate a better deal. In contrast, a bestseller clause does not adequately address the prediction problem, and will rarely avail authors of bargains that seem inadequate in hindsight.

75 Tristan Azzi "General Report: Mechanisms to Ensure Adequate Remuneration for Creators and Performers" in Silke von Lewinski (ed) Remuneration for the Use of Works: Exclusivity vs Other Approaches (De Grutyer, Berlin, 2017) 85 at 89.

76 See Senftleben, above n 70, at 57-58, observing that while the German amendments have served as a model for reforms in some other countries, most notably the Netherlands, the problem remains as to how legislation requiring equitable payment for authors can be made effective in practice.

77 Gutsche, above n 74 , at 271 .

78 According to Hilty and Peukert the provisions apply to authors from Germany, European Union Member States and the European Economic Area but extend to foreign authors only in limited circumstances. Dietz argues that the provisions constitute "rights" under the Berne Convention, above n 54, and TRIPS Agreement, above $\mathrm{n} 54$, therefore national treatment applies and foreign authors can also rely on them: Reto Hilty and Alexander Peukert "Equitable Remuneration in Copyright Law: The Amended German Copyright Act as a Trap for the Entertainment Industry in the US?" (2004) 22 Cardozo Arts \& Ent LJ 401 at 443; and Adolf Dietz "Amendment of German Copyright Act in Order to Strengthen the Contractual Position of Authors and Performers" (2002) 33 IIC 828 at 840.

79 Gutsche, above n 74, at 358 .

80 Stella Brown "It Takes a Village to Make a Difference: Continuing the Spirit of Copyright" (2014) 12 Nw J Tech \& Intell Prop 129 at 133. 
First, a bestseller clause will usually provide authors with relief only if they are remunerated by lump sum payment as opposed to royalties. ${ }^{81}$ The income of authors who receive royalties will automatically increase if their works later become successful. This will leave the proportion of their income relative to industry proceeds unchanged, and hence their remuneration will not become conspicuously disproportionate. ${ }^{82}$ For example, in the 1930s Joe Shuster and Jerry Siegel sold their copyrights to Superman for the market rate, USD $130 .{ }^{83}$ While DC Comics got rich, Shuster and Siegel did not, ${ }^{84}$ and were haunted by their disastrous transfer until their deaths. ${ }^{85}$ Under the German bestseller clause, Shuster and Siegel's proceeds would certainly be considered conspicuously disproportionate, entitling them to further equitable participation. In contrast, Duran Duran's remuneration is determined by royalty payments. ${ }^{86}$ The income received by the band members has therefore adjusted proportionately to the success of their works. As a result, they would be unable to successfully seek recourse and claim further equitable participation under the bestseller clause. The United States termination right does not distinguish between these scenarios and would apply equally to Duran Duran. Because music and publishing industries typically remunerate authors via royalties, adopting a bestseller clause in New Zealand will not provide redress for many successful authors beyond the royalty rate stipulated in their contracts. ${ }^{87}$

Even if bestselling authors could rely on either scheme, a termination right is more likely to yield lucrative rewards than a bestseller clause. Authors seeking to retrieve their New Zealand copyrights under a termination right will have a valuable bargaining chip in hand for their renegotiations, though this will admittedly be of modest value beside the significant market for copyright works in the United States. In contrast, authors whose remuneration is conspicuously disproportionate under a bestseller clause will receive some "additional" payment as deemed appropriate. ${ }^{88}$ Because this amount need

81 Wilhelm Nordemann "A Revolution of Copyright in Germany" (2002) 49 J Copyright Socy 1041 at 1045.

82 Karsten Gutsche "New Copyright Contract Legislation in Germany: Rules on Equitable Remuneration Provide 'Just Rewards' to Authors and Performers" (2003) 25 EIPR 366 at 368.

83 Michael Farquhar Bad Days in History: A Gleefully Grim Chronicle of Misfortune, Mayhem, and Misery for Every Day of the Year (National Geographic Society, Washington DC, 2015) at 88.

84 Andrew Paster "Rethinking Copyright Termination in a Global Market: How a Limitation in US Copyright Law Could Be Resolved by France's Droit d'Auteur" (2017) 23 Sw J Intl L 375 at 376.

85 Robert McGill Thomas Jr "Jerry Siegel, Superman's Creator, Dies at 81" The New York Times (online ed, New York, 31 January 1996).

86 Gloucester Place Music Ltd v Le Bon, above n 2, at [2].

87 Peter DiCola "Money From Music: Survey Evidence on Musicians' Revenue and Lessons About Copyright Incentives" (2013) Ariz L Rev 301 at 306.

88 German Copyright Act, s 32a(1). 
only be proportionate to industry revenue, fully recapturing the right to exploit their copyright in New Zealand will provide bestsellers with the better deal.

On first impression, it may seem that bestselling authors who receive royalties do not need a reevaluation mechanism. ${ }^{89}$ For instance, Duran Duran members Simon Le Bon and Nick Rhodes are each worth USD 60 million. ${ }^{90}$ But focusing on what bestselling authors "need" misses the point. Instead, the moral case is that when corporate entities reap a "gazillion dollars" of which the author sees but a fraction, this is unjust, and authors deserve better treatment. ${ }^{91}$ As the Duran Duran saga illustrates, this argument has considerable force, particularly when authors have unknowingly and irreversibly sold their rights at a young age for what in hindsight seems a pittance.

Termination rights can alleviate the prediction problem by giving bestselling authors a "second bite at the apple" once they have realised the true value of the rights that they have signed away. ${ }^{92}$ Provided that their works are still valuable, renegotiations with disseminators will almost invariably provide bestsellers with a more lucrative deal. ${ }^{93}$ If the purpose of copyright is to reward authors, not just to give them enough to get by, adopting a termination right in New Zealand is worthy of serious consideration. ${ }^{94}$ For the reasons that follow, however, optimism is premature.

\section{B Beyond Bestsellers}

Most authors will not benefit if a termination right is adopted in New Zealand. Media attention has typically focused on well-known superstar authors such as Paul McCartney, ${ }^{95}$ Victor Willis, ${ }^{96}$ and Duran Duran, who have undersold their rights and sought redress under the United States

89 Melville Nimmer "Termination of Transfers Under the Copyright Act of 1976" (1977) 125 U Pa L Rev 945 at 950 .

90 Celebrity Net Worth "Nick Rhodes Net Worth" and "Simon Le Bon Net Worth" <www.celebrity networth.com>.

91 Larry Rohter "Record Industry Braces for Artists' Battles Over Song Rights" The New York Times (online ed, New York, 15 August 2011) quoting Eagles and Recording Artists' Coalition founder Don Henley: "In terms of all those big acts you name, the recording industry has made a gazillion dollars on those masters, more than the artists have".

92 Guy Rub "Stronger Than Kryptonite? Inalienable Profit-Sharing in Copyright Law" (2013) 27 Harv J L \& Tech 49 at 55; and Gilbert, above n 59, at 808 .

93 Steven Bolanos "'Knock, Knock, Knockin' on [Congress's] Door": A Plea to Congress to Amend Section 203 of the Copyright Act of 1976" (2014) 41 W St U L Rev 391 at 409.

94 Giblin, above n 21, at 192.

95 Ben Sisaro "Paul McCartney Sues to Get Back His Beatles Songs" The New York Times (online ed, New York, 18 January 2017).

96 Larry Rother "A Copyright Victory, 35 Years Later" The New York Times (online ed, New York, 10 September 2013). 
termination right. For those who do not enjoy superstar success, the effects of the right are not so clear, and require further scrutiny. At best, termination rights are unusable by most authors and thus fail to address the structural inequality within copyright industries. At worst, they may exacerbate that inequality.

Termination rights may harm the interests of authors, rather than do them any good. Only the most successful works will remain valuable in the longer term, and the authors of these works will likely exercise their termination rights. ${ }^{97}$ Accordingly, parties will enter contracts understanding that, if the works are profitable when the termination right becomes available, the author will require renegotiation or else pursue a better deal elsewhere. Hence disseminators will no longer be assured of retaining the rights for the full copyright term - a considerable loss, ${ }^{98}$ as the copyright in most works lasts for the author's lifetime, and 50 years beyond that.$^{99}$ Disseminators will thus anticipate receiving a lower payoff in the event that an author's work becomes successful, and consequently will place less value on new contracts with unknown authors. ${ }^{100}$ As the expected returns decrease, so does willingness to pay. Essentially, the cost of bestsellers filing to retrieve their copyrights in the future is likely to be felt by authors taking an initial pay cut under their contracts. ${ }^{101}$ The prospect of authors later offsetting this effect by recapturing their copyrights or renegotiating a better deal will never materialise for most. ${ }^{102}$ Accordingly, while the purpose of the United States provision was "safeguarding authors against unremunerative transfers", a closer analysis suggests that termination rights are instead likely to expose authors to more of these transfers. ${ }^{103}$ Overwhelmingly, incomes in creative industries are already skewed in "winner takes all" patterns. ${ }^{104}$ While a select few receive extraordinarily high earnings, average incomes fall well below the median level. ${ }^{105}$ Because the real beneficiaries of termination rights are bestselling authors, critics of the United States provision have likened it to a regressive tax, transferring income from those who need it most, to those who need it

97 Matthew Noller "Darkness on the Edge of Town: How Entitlements Theory Can Shine a Light on Termination of Transfers in Sound Recordings" (2012) 46 Ga L Rev 763 at 787.

98 Kate Darling "Occupy Copyright: A Law \& Economic Analysis of U.S. Author Termination Rights" (2015) 63 Buff L Rev 147 at 166.

99 Copyright Act, s 22(1).

100 Gilbert, above n 59, at 810 .

101 Brown, above n 80, at 147.

102 Darling, above n 98, at 166 .

103 HR Rep No 94-1476 at 124 (1976).

104 Martin Kretschmer "Copyright and Contract Law: Regulating Creator Contracts: The State of the Art and a Research Agenda" (2010) 18 J Intell Prop L 141 at 149-150.

105 Ruth Towse "What We Know, What We Don't Know, and What Policy-Makers Would Like us to Know About the Economics of Copyright" (2011) 8 Review of Economic Research on Copyright Issues 101 at 107. 
least. ${ }^{106}$ If this is the case, termination rights are antithetical to the very purpose of re-evaluation mechanisms, which are designed to protect authors in vulnerable positions. ${ }^{107}$

Even if a termination right does not harm most authors, in any event, it offers them no relief. Termination rights will place authors in stronger positions vis-à-vis disseminators only if their works remain valuable when they may first recapture their copyrights. Needless to say, few works will be worth anything after 35, 20 or even 15 years. It follows that, even if authors do not have to wait a full 35 years to exercise their termination rights, this will offer little comfort at the start of their careers when they are most in need of income. ${ }^{108}$ Adopting such a right in the New Zealand Copyright Act will thus not address the crux of the problem - that is, an inequality of bargaining power within copyright industries. While enabling authors to recapture their rights is superficially attractive, termination rights intervene far too late to provide authors with solutions when a re-evaluation mechanism is most needed.

\section{Enforcing Re-evaluation}

A requirement that authors must be fairly paid seems to promise more. ${ }^{109}$ However, the difficulty is that authors are unlikely to enforce such a requirement if they must confront stronger parties. This gives re-evaluation rhetoric a strong dose of realism. Although re-evaluation mechanisms that mandate "equitable" payment for authors under their contracts are attractive in theory, they are unduly optimistic.

For authors without bargaining power, long-term career prospects are likely to prevail over enforcing such re-evaluation rights even when entitled to do so. There is typically an oversupply of authors in creative industries, ${ }^{110}$ and the competition for publishing contracts can be fierce. ${ }^{111}$ Accordingly, authors will be conscious that they can easily be replaced with someone more compliant if they object to the terms on offer, thus losing a sought-after publishing opportunity. Negotiating better terms is rarely an option, and authors are still likely to accept contracts deemed unsatisfactory under such a re-evaluation mechanism if the alternative is being left with no contract at all. ${ }^{112}$ After securing a publishing contract, authors may still be hesitant to enforce their rights for fear of being

106 Kal Raustiala and Christopher Sprigman "The Music Industry Copyright Battle: When is Owning More Like Renting" (31 August 2011) Freakonomics <www.freakonomics.com>.

107 Darling, above n 98, at 150 .

108 At 167.

109 German Copyright Act, s 32 .

110 Alexander Dolgin The Economics of Symbolic Cultural Exchange (Springer, Berlin, 2009) at 306.

111 Anderson, above n 52, at 846.

112 Theo Papadopoulos "Are Music Recording Contracts Equitable? An Economic Analysis of the Practice of Recoupment" (2004) 4 MEIEA Journal 83 at 85. 
blacklisted. ${ }^{113}$ If required to confront stronger parties, authors will need to balance the chance of securing a better deal with the possibility of irreparably damaging the relationship with their disseminator. Careers are at stake, and future opportunities may well be prejudiced should this relationship turn hostile. ${ }^{114}$ Keeping quiet to maintain goodwill is likely to be the safer and more pragmatic option. Beyond this relationship, authors will be wary of gaining a negative reputation in the wider industry for being an irksome contracting partner. ${ }^{115}$ Particularly in close-knit industries, such a reputation would presumably take a heavy toll on an author's future opportunities.

These difficulties have been apparent in Germany. Under the German Copyright Act, authors must face stronger parties should they wish to enforce their rights under the provisions. Even if the contract obviously falls short of the standards required under the Act, the author will need to confront disseminators to duly inform them of their failure to meet said standards. ${ }^{116}$ One commentator has remarked that as a result, "pragmatism prevails over the application of the rules of law" in the context of the amendments. ${ }^{117}$ In other words, while these reforms certainly appear revolutionary for authors in theory, they have not been so in practice. ${ }^{118}$ It has not so far proven workable to enforce equitable payment for authors with this particular re-evaluation mechanism. Accordingly, domestic policymakers should refrain from "window-dressing" in the New Zealand Copyright Act, and avoid such reforms that will not achieve their purpose.

\section{Interests of Disseminators}

Disseminators play a vital role in the copyright system by delivering works to the public, market expertise and investment in authors. Their interests are unlikely to align with a re-evaluation mechanism that provides authors with a greater proportion of the copyright revenue. ${ }^{119}$ Particularly in relation to a termination right, domestic policymakers had best be advised that disseminators do have a compelling case.

113 Nikolaus Reber "The 'Further Participation' Provision in Art. 32a(2) German Copyright Act - Claims Against a Third-Party Exploiter of a Work" (2016) 11 JIPLP 382 at 383.

114 Azzi, above $\mathrm{n} 75$, at 97.

115 William Cornish "The Author as Risk-Sharer" (2002) 26 Colum J L \& Arts 1 at 10.

116 Silke von Lewinski "Collectivism and its Role in the Frame of Individual Contracts" in Jan Rosen (ed) Individualism and Collectivism in Intellectual Property Law (Edward Elgar Publishing, Cheltenham, 2012) 117 at 120 .

117 Azzi, above n 75, at 97.

118 See Nordemann, above $\mathrm{n} 81$.

119 Jessica Johnson "Application of the Copyright Termination Provision to the Music Industry: Sound Recordings Should Constitute Works Made for Hire" (2013) 67 U Miami L Rev 661 at 674. 
The first issue is that termination rights may deprive disseminators of proceeds generated by their own efforts. ${ }^{120}$ Investment in merchandising, the establishment of global networks and the provision of resources and expertise may be inextricably connected with the success of an author's work. ${ }^{121}$ Although digital technology has allowed some to self-publish, ${ }^{122}$ disseminator investment often remains vital in order to produce quality works that get noticed amid floods of content. ${ }^{123}$ In the music industry for instance, expensive technology is often required for artists to become global bestsellers. As such, disseminators' claims that "[m]aking great content requires investment" have merit. ${ }^{124}$ Because authors can fully recapture their copyrights under a termination right, there is no distinction between their contributions on the one hand, and disseminators' contributions on the other. Thus in exercising the right, authors may enjoy the fruits of disseminators' labour as well as their own. ${ }^{125}$

Disseminators also share the prediction problem, ${ }^{126}$ and a termination right overlooks their investment risk. ${ }^{127}$ Typically, disseminators will invest in multiple authors, each with a very small chance of success. Although heavy losses are incurred when authors are unsuccessful, these can be absorbed due to large profits made from bestselling works, ${ }^{128}$ allowing disseminators to mitigate the risk of investing in those who are just beginning their careers. ${ }^{129}$ This arrangement is mutually beneficial, as authors who cannot shoulder the cost of failure may hand this risk to disseminators who can. ${ }^{130}$ In return, disseminators can expect to receive the greater share of revenue in the unlikely event that a work becomes successful. ${ }^{131}$ By allowing bestselling authors to recapture their copyrights, termination rights undermine this initial allocation of risk. ${ }^{132}$

120 Anderson, above n 52, at 843; and Reese, above n 50, at 740.

121 Brian Day "In Defense of Copyright: Record Labels, Creativity, and the Future of Music" (2011) 21 Seton Hall J Sports \& Ent L 61 at 78; and Gilbert, above n 59, at 816.

122 Ivan Pitt Economic Analysis of Music Copyright: Income, Media and Performances (Springer, New York, 2010) at 71 .

123 At 78 .

124 Ministry of Business, Innovation and Employment Copyright and the Creative Sector (December 2016) at 22 quoting an unnamed record company.

125 Reese, above n 50, at 707 .

126 Gilbert, above n 59, at 820 .

127 Rub, above n 92, at 97.

128 Gilbert, above n 59, at 817 .

129 Papadopoulos, above n 112, at 90.

130 Darling, above n 98, at 164.

131 Gilbert, above n 59, at 817.

132 Day, above n 121, at 75. 
Adopting a termination right may also curb the production of new works. ${ }^{133}$ Copyright industries have traditionally been heavily dependent on capital from a small handful of bestselling works to reinvest into making new ones. ${ }^{134}$ Because bestsellers are inclined to exercise their termination rights, the available funds for new investment will likely decrease. With less to go around, fewer upcoming authors can expect to receive support from disseminators for creating new works. ${ }^{135}$ In this respect, one unintended effect of termination rights that supposedly support authors' endeavours may be reducing their opportunities to produce creative works overall.

These arguments are perhaps less convincing as distribution and production costs decline, ${ }^{136}$ and, in light of new technology enabling the cheaper, faster delivery of works, disseminators should not retain the lion's share of revenue if their justifications are outdated. ${ }^{137}$ While true to an extent, these considerations should not be overstated. Wholly self-publishing industries have not yet materialised, and disseminators are still needed. ${ }^{138}$ Although introducing a termination right in New Zealand is unlikely by itself to bring disseminators to financial ruin, their concerns cannot be dismissed, and provide forceful reasons against adopting these kinds of reforms. ${ }^{139}$

Regulating authors' contracts, as under the German scheme, appears to be less radical for disseminators. For one, disseminators who already provide authors with equitable, proportionate rewards will be unaffected by the provisions. ${ }^{140}$ When the provisions do intervene, they will notunlike a termination right - confiscate a disseminator's ability to exploit the copyrights. Instead, disseminators will be required only to provide authors with some additional payment on fairer terms. Compared to the "all or nothing" approach of termination rights, such a re-evaluation mechanism offers a preferable compromise in terms of balancing the interests of disseminators.

Even so, such a scheme will no doubt be politically controversial if proposed in New Zealand. Copyright reforms are notoriously contentious, particularly if they will alter the dynamics between

133 Anderson, above n 52, at 193.

134 Gilbert, above n 59, at 815 .

135 Darling, above n 98, at 193.

136 Molly Van Houweling "Author Versus Owner" (2016) 54 Hous L Rev 371 at 378.

137 Jessica Litman "Real Copyright Reform" (2010) 96 Iowa L Rev 1 at 21.

138 Francina Cantatore "The Power Balance Revisited: Authors, Publishers and Copyright in the Digital Sphere" (2013) 6 Creative Industries Journal 89 at 102.

139 Van Houweling, above n 136, at 385.

140 Frank Curtis "Protecting Authors in Copyright Transfers: Revision Bill Section 203 and the Alternatives" (1972) 72 Colum L Rev 799 at 836. 
competing stakeholders, ${ }^{141}$ and German publishers vehemently opposed the 2002 amendments. ${ }^{142}$ Such opposition should not, in isolation, preclude domestic policymakers from adopting the German approach in the New Zealand Copyright Act, but is nevertheless worth bearing in mind.

\section{E Arbitrary Outcomes}

For a re-evaluation mechanism to be worthwhile, it must allow authors to seek relief when relief is needed. The German scheme does so, as those receiving inequitable or conspicuously disproportionate remuneration are entitled to redress. Termination rights however, operate on set dates, and are blind to all else. Accordingly, they are blunt economic tools, and are unable to provide authors with consistent solutions.

The first issue is that different types of work have varying life spans. For example, while demand for a popular song might last only several years, a famous novel may be profitable for much longer. Unaffected by such differences, termination rights apply in the identical manner across a wide range of works. ${ }^{143}$ No distinction is made between types of works likely to remain successful for a long period of time and those that are not. As to why certain types of work should be more apt than others to provide their creators with rewards under a re-evaluation mechanism, no principled explanation can be given.

Second, termination rights cannot reliably address the prediction problem. An author's prospects of relief hinge entirely on the value of his or her works at the earliest termination date. Unless that value is considerable, no relief is provided. Even the most popular works do not remain profitable in perpetuity, and bestselling authors who fall out of favour before they can recapture their rights are denied any benefits that a termination right might otherwise have offered. It is difficult to see why an author should benefit if his or her works remain profitable after 35 years, but should not benefit if profitability has waned after only 30 years. For all relevant purposes these cases are identical, and to treat them differently is arbitrary. The 35-year time period stipulated in the United States termination right is especially problematic, and reflects a competition between stakeholders as opposed to a decision based on sound evidence or policy. ${ }^{144}$ A small proportion of copyrights are worth recapturing after 35 years, and few living authors will benefit from the provision. ${ }^{145}$ Allowing authors to recapture their rights earlier would alleviate the harshness of the United States termination right to some extent, and leading commentators have suggested that such an adjustment is well overdue. ${ }^{146}$ All the same,

141 Litman, above n 137, at 5.

142 Hilty and Peukert, above n 78, at 436.

14317 USC $\S 203(a)$.

144 Jessica Litman "Copyright, Compromise and Legislative History" (1987) 72 Cornell L Rev 857 at $892-893$.

145 Curtis, above n 140, at 819 .

146 Litman, above n 137, at 48; and Curtis, above n 140, at 834. 
the arbitrariness of any termination right will persist regardless of the specific number of years that might be chosen by domestic policymakers.

\section{F Encouraging Creativity}

Encouraging the creation of new works has been identified by the Ministry of Business, Innovation and Employment as a core objective of copyright in New Zealand. ${ }^{147}$ This has been rehearsed in the context of the terms of reference for the New Zealand Copyright Act review. If reevaluation mechanisms encourage authors to create new works, such a reform may be useful for furthering this objective in New Zealand. The question is: can a re-evaluation mechanism really encourage creativity?

There are many different reasons for doing creative work aside from financial incentives, such as self-expression, reputation and storytelling. ${ }^{148}$ While this is true, authors too must live, and a day job can hinder creative endeavours. For example, not benefitting from their copyrights to Superman, Shuster spent his days working as a messenger, and Siegel as a typist. ${ }^{149}$ For authors on lower incomes at least, receiving additional income thanks to a re-evaluation mechanism could make a vital difference, allowing them to spend the time necessary for creating new works. The limits of reevaluation mechanisms should be noted however, and if an author's works are simply unprofitable, then clearly such a scheme will provide no relief. ${ }^{150}$

Authors' rewards are also important for normative reasons. ${ }^{151}$ If they receive meagre proceeds from their works compared to industry profits, this implies that they are insufficiently valued, which may well discourage creativity. Human rights instruments have drawn this connection between an author's income and the intrinsic value of authorship. ${ }^{152}$ And by safeguarding authors' "material interests", re-evaluation mechanisms have been expressly identified by the United Nations Special Rapporteur in the field of cultural rights as vehicles to uphold the human right of authorship protection. ${ }^{153}$ In recognising authors' rights and affording them dignity, the ideal re-evaluation

147 Ministry of Business, Innovation and Employment, above n 124, at 7.

148 Laura Heyman "A Tale of (At Least) Two Authors: Focusing Copyright Law on Process Over Product" (2009) 34 J Corp L 1009 at 1010.

149 McGill Thomas Jr, above n 85.

150 Towse, above n 105, at 117

151 Ruth Towse "Partly for the Money: Rewards and Incentives to Artists" (2001) 54 Kyklos 473 at 482.

152 Universal Declaration of Human Rights GA Res 217A III (1948), art 27(2); and International Covenant on Economic, Social and Cultural Rights 993 UNTS 3 (opened for signature 16 December 1966, entered into force 3 January 1976), art 15(1)(c).

153 Farida Shaheed, Special Rapporteur on Cultural Rights Copyright policy and the right to science and culture UN Doc A/HRC/28/57 (2014) at 10. 
mechanism would go beyond simply allowing authors the income required to purchase household necessities. Rather, it would also signal that they were valued and worthy of such protection, thus supporting creative endeavours.

In reality, however, a termination right is unlikely to foster creativity to any great extent. First, people will favour immediate benefits over benefits for which they must wait, ${ }^{154}$ and any rewards from termination rights will not arrive until decades after an author creates his or her works. ${ }^{155}$ As such, the prospect of exercising a termination right at age 60 will not figure greatly in the mind of a 25 -year-old about to create new work. Creators over the age of 40 need not think of it at all. Secondly, future benefits are even less valuable if they are uncertain and may never actually materialise. ${ }^{156}$ The likelihood that the works will be both successful and retain this success until the author can recapture the copyrights is small, which further erodes the prospect of termination rights encouraging creativity. ${ }^{157}$ The value of future benefits dwindles further if individuals envision a sizeable increase in their incomes before receiving these benefits. By the time a termination right falls due, a bestselling author is likely to have already reaped the rewards of a successful career. Even if authors do picture themselves decades in the future, expectations of a bestseller's income will undermine the significance of any rewards that might be collected from recapturing their copyrights. It is hard to see, at any stage, a termination right increasing an author's desire to create new works.

The German scheme appears more promising for encouraging creativity. Authors need not wait half a lifetime in the hope of some conceivable, but highly unlikely, benefit that they may never live to see. Instead, they may invoke the provisions when their remuneration is inequitable or conspicuously disproportionate. If a re-evaluation mechanism is to have any effect on creativity, it must intervene relatively early as opposed to some point in the distant future. ${ }^{158}$ In addition, the provisions are designed to secure fair remuneration from the outset, and to assist authors at the bottom of the income ladder. If authors can survive on creative incomes, this allows them to dedicate time to creating new works should they wish to do so. However, while logically sound, the outcome is not quite so linear. Such a scheme is unlikely to be enforced by authors without bargaining power and, as I outline below, suffers from extensive practical difficulties. Consequently, domestic policymakers

154 This is known in economics as the discounting effect. See John Black, Niger Hashimzade and Gareth Myles Oxford Dictionary of Economics (5th ed, Oxford University Press, New York, 2017).

155 Darling, above n 98, at 178.

156 At 183

157 See Eldred v Ashcroft 537 US 186 (2003) at 254. In the context of the 1998 Sonny Bono Copyright Term Extension Act extending United States copyright by 20 years, Breyer J dissenting stated: "No potential author can reasonably believe that he has more than a tiny chance of writing a classic that will survive commercially long enough for the copyright extension to matter."

158 Curtis, above n 140, at 819. 
should not overestimate the prospect of increasing authors' creativity by way of introducing such reforms in New Zealand.

\section{G Third Party Profits}

Third parties will often enjoy the bulk of revenue from an author's work. ${ }^{159}$ Re-evaluation mechanisms that give authors no way of holding third parties to account are thus incapable of providing real solutions. A termination right deals swiftly with the issue. When an author files a termination notice, third parties will need to negotiate with the author directly should they wish to continue exploiting the copyrights. ${ }^{160}$

In contrast, accounting for third party exploitation becomes a significant problem if authors' contracts are regulated. Authors cannot recover their grants under such a scheme, hence requiring them to investigate both exactly who is profiting from their works and by how much, to determine their entitlements from third parties. Partly to address this problem, as of March 2017 the German Copyright Act empowers authors to request such information annually from their contracting partners and subsequent grantees. ${ }^{161}$ The purpose of this change appears to have been to make the German scheme more workable for authors, thus remedying its ineffectiveness. It remains uncertain whether such an information right will improve the usefulness of the amendments and their ability to provide authors with relief. In any event, claiming from third parties under such a scheme is still likely to prove complex for authors, particularly when profits from their works are divided among numerous recipients.

\section{H Uncertainty}

Uncertainty can derail well-meaning reforms. Although termination rights are "mechanical" and arbitrary, this allows them to provide relative clarity. ${ }^{162}$ Authors will know exactly when they can exercise their termination rights, and that should they do so, they will regain their copyrights. Anticipating this result, authors and disseminators are able to plan accordingly, and renegotiate an appropriate bargain.

Reforms that rely on concepts of "fairness" risk becoming hamstrung by uncertainty. Fifteen years after the 2002 amendments in Germany, it remains unclear exactly when an author's remuneration will be considered inequitable or conspicuously disproportionate - a cautionary tale for domestic policymakers. ${ }^{163}$ These standards are qualitative, and so determinations must be made for each

159 Reber, above n 113, at 383 .

16017 USC $\S 203$ (b)

161 German Copyright Act, ss 32d-32e.

162 Curtis, above n 140, at 845 .

163 Senftleben, above n 70, at 53. 
particular agreement. ${ }^{164}$ Clearer definitions are wanted, and specific factors indicating whether an author's remuneration will be considered equitable. ${ }^{165}$ According to the explanatory note to the German amendments, such factors might include market conditions, disseminator investment and risk, number of copies produced and expected proceeds. ${ }^{166}$ However, even if domestic policymakers were to provide more detailed criteria this would still not relieve such a scheme of uncertainty. For one, it might not even be possible to decide how copyright revenue ought to be equitably divided. ${ }^{167}$ While few would disagree that authors should be paid "fairly", fewer would agree on what that requires. Standards of fairness are unavoidably subjective, and outcomes reached by applying such standards are difficult to predict accurately. ${ }^{168}$ Findings of "inequitable" or "conspicuously disproportionate" remuneration will also be contingent on factors such as an author's particular industry, type of work and method of receiving income. ${ }^{169}$ Such factors will vary between authors and, without clear precedent, outcomes will be uncertain.

\section{Administrative Complications}

Idealism aside, administering a re-evaluation mechanism must be workable for reform. For policymakers in a small jurisdiction like New Zealand, this pragmatic factor is a critical issue. Introducing any such mechanism will doubtless increase administrative workload and costs, but particularly in the case of regulating authors' contracts.

If authors' contracts are to be assessed, domestic policymakers will first need to decide which authority will be responsible for this appraisal. Under the German scheme, the courts are tasked with assessing copyright contracts when the parties cannot agree. ${ }^{170}$ This presents an obvious problem, as the cost of taking a full lawsuit deters authors from invoking the provisions. ${ }^{171}$ The New Zealand Copyright Tribunal was established mainly to prevent copyright owner monopoly, and assesses proposed licensing schemes and file sharing infringement. ${ }^{172}$ If the German approach were adopted

164 Hilty and Peukert, above n 78, at 432.

165 Senftleben, above n 70, at 58-59.

166 Hilty and Peukert, above n 78, at 431.

167 At 430 .

168 Kate Tokeley "Introducing a Prohibition on Unfair Contractual Terms into New Zealand Law: Justifications and Suggestions for Reform" (2009) 23 NZULR 419 at 424.

169 Martin Schippan "Codification of Contract Rules for Copyright Owners - the Recent Amendment of the German Copyright Act" (2002) 24 EIPR 171 at 172.

170 Senftleben, above n 70 , at 53 .

171 Dietz, above n 78, at 838 .

172 Copyright Act, ss 122J and 149-160; and Peter Spiller "The Copyright Tribunal (1989-2008): An Assessment" [2009] NZLJ 193 at 193. 
in New Zealand, the Copyright Tribunal might provide a less costly and more efficient alternative to the courts for assessing authors' contracts. The Tribunal is currently empowered to set the rate of remuneration paid to copyright owners or licensees in limited circumstances. ${ }^{173}$ While this rarely occurs, it does provide some foundation for the Tribunal to assess authors' remuneration and to set an acceptable rate if required. ${ }^{174}$ As the Copyright Tribunal comprises one chair and five members, and hears few disputes annually, its jurisdiction and resources would need to be substantially increased if presented with a new and more active role. ${ }^{175}$

Enforcement is also essential. Deeming an author's remuneration to be inadequate will ring hollow if the contracting partner does not increase this amount accordingly. ${ }^{176}$ Domestic policymakers must consider enforcement in the context of the international market for copyright works. When authors have contracted with overseas disseminators, the responsible authority will need to impose its rulings on international copyright contracts, monitor compliance and enforce its decisions if necessary. ${ }^{177}$ This adds further complexities to regulating authors' contracts under the New Zealand Copyright Act. Facing these obstructions might be justified if this reform would deliver real solutions. But, as I have argued above, adopting such a scheme is unlikely to provide tangible benefits for either bestsellers or vulnerable authors. In light of this, any purported benefits of such a reform are outweighed by its practical difficulties.

Administering a termination right is feasible, but not without difficulty. If a termination right is adopted in the New Zealand Copyright Act, some form of record keeping and oversight will presumably be required. In the United States, the United States Copyright Office performs all administrative functions for the United States termination right, and deals with the registration of copyrights. ${ }^{178}$ Although registration is not mandatory under the United States Copyright Act, ${ }^{179}$ it

173 The Tribunal may determine the rate of "equitable remuneration" where the copyright owner and a librarian cannot agree as to the remuneration paid to the copyright owner under s 54(2)(d), a copyright owner and the Crown cannot agree on remuneration under s 63(2), an exclusive licensee cannot agree on remuneration under s 64(2) or a copyright owner and a person who makes a recording of a communication work cannot agree on remuneration under s 91(2)(d): Copyright Act, s 168.

174 The New Zealand Copyright Tribunal will specify a remuneration rate only if the matter goes to a full hearing which rarely occurs: Jane Ginsburg "Fair Use for Free or Permitted but Paid?" (2014) 29 Berkeley Tech LJ 1383 at 1422.

175 Under s 206(1) of the Copyright Act the Copyright Tribunal consists of a chairperson and at least two, but not more than five, other persons.

176 Hilty and Peukert, above n 78, at 448-449.

177 Alexander Peukert "Protection of Authors and Performing Artists in International Law - Considering Claims for Equitable Remuneration Under German and Italian Copyright Law" (2004) 35 IIC 900 at 921.

17817 USC $\$ 701(a)$.

$179 \S 408(a)$. 
provides benefits to copyright owners by creating a permanent record of their claim to the work, ${ }^{180}$ and is required to sue for copyright infringement and to get the benefit of statutory damages and attorney's fees. ${ }^{181}$ There is currently no such copyright registration system in New Zealand. Although the Intellectual Property Office of New Zealand (IPONZ) grants and registers national intellectual property rights, it does not register copyrights, and deals primarily with trademarks, patents and designs. ${ }^{182}$ Requiring the IPONZ to oversee a termination right would thus be a significant divergence from its current role, and precisely how it would fulfil such a function is unclear. As there is currently no existing authority that is readily able to administer a termination right in New Zealand, adopting this reform would introduce administrative work and associated expense to an unknown extent.

Perhaps most crucially, termination rights are designed to encourage private renegotiations. ${ }^{183}$ Faced with an author's termination notice, disseminators will need to compare the costs of potentially unsuccessful court proceedings, losing the New Zealand copyrights and a revised agreement. In this situation, renegotiation will often be the preferred option. ${ }^{184}$ Much of the real work of termination rights can thus be carried out between the parties, reducing the potential administration, litigation and cost of introducing a re-evaluation mechanism. Still, some disputes will undoubtedly occur. It follows that, notwithstanding the likely prevalence of private renegotiations, both the administration and litigation of such a scheme will be in uncharted waters.

\section{J Further Difficulties}

\section{Foreign authors}

If considering a re-evaluation mechanism for New Zealand, policymakers must decide whether it will be available to all, or only to domestic authors. ${ }^{185}$ Difficulties will be encountered regardless of which option is chosen. The arguments for choosing the former are certainly compelling. Globally, authors face weak bargaining positions and the prediction problem, and hence the rationale of adopting a re-evaluation mechanism applies equally, regardless of nationality. This is also consistent with the interests of domestic authors, as disseminators may be reluctant to invest in these individuals

180 Mark Warda How to Register Your Own Copyright (5th ed, Sphinx Publishing, Illinois, 2004) at 38.

18117 USC $\S \S 411($ a) and 412.

182 New Zealand Intellectual Property Office <www.iponz.govt.nz>.

183 Andrew Paster "Rethinking Copyright Termination in a Global Market: How a Limitation in US Copyright Law Could Be Resolved by France's Droit d'Auteur" (2017) 23 Sw J Intl L 375 at 391.

184 Scott, above n 58, at 57.

185 The national treatment obligation might be avoided by reforms under contract law as opposed to copyright. See Hilty and Peukert, above $\mathrm{n} 78$, at 401 . This issue will need to be addressed if reform is proposed, but is not explored in any further depth in this article. 
if they perceive that doing so will involve obligations that are not applicable to others. ${ }^{186}$ If so, adopting a scheme that applies to only domestic authors will place them in a worse position than before. However, these arguments face pragmatic challenges. As emphasised at the start of this article, New Zealand is a net importer of copyright works. ${ }^{187}$ This means that more foreign works are exploited in New Zealand than domestic works. It follows that, if a re-evaluation mechanism does apply to all, the administrative demands of such a scheme will be driven by content from overseas. Limiting redress to domestic authors stands on shakier idealistic ground, but sits more firmly within the bounds of possibility, as disputes will undoubtedly arise much less frequently.

\section{Existing copyright legislation}

Domestic policymakers will also need to consider the extent to which any proposed reforms will align with existing copyright legislation. While the New Zealand Copyright Act does contain some references to broad concepts such as "equitable remuneration", these provisions are outliers in the Act. ${ }^{188}$ Such a pattern is consistent with copyright in the United Kingdom tradition. According to leading commentator von Lewinski, authors' rights systems (of which Germany is one) typically tend to be more abstract and "principles-based" in comparison to Common Law copyright systems that prefer systemic definitions. ${ }^{189}$ While not precluding the adoption of a re-evaluation mechanism such as the German scheme, this implies that domestic policymakers should be wary about importing such a "civil law" approach into the New Zealand Copyright Act.

\section{CONCLUSION}

Weak bargaining positions, and the need to bind themselves to contracts when the value of their works is yet unknown have left authors in a troubling position. In a system that does not seem to value authorship, the livelihoods, dignity and human rights of authors are at stake. And with the New Zealand Copyright Act under review, it is imperative to consider reform. By exploring two reevaluation mechanisms that might potentially be adopted, this article has sought to address that need.

Neither option, however, offers solutions. The United States termination right is blunt, arbitrary, and not only incapable of assisting authors when needed but likely to deprive them from the outset. Similarly, while the German scheme seems appealing, it is flawed by uncertainty and by obliging authors to enforce their rights against disseminators far more powerful than themselves. It would also be unwise to ignore the practicalities of such reforms, and bringing either approach into New Zealand will necessarily require oversight of an uncertain, and potentially insurmountable, scale.

186 Jane Ginsburg and Pierre Sirinelli "Private International Law Aspects of Authors' Contracts: The Dutch and French Examples" (2015) 39 Colum J L \& Arts 171 at 189.

187 Woods, above n 22, at 35 .

188 Copyright Act, ss 54(2)(d), 63(2), 64(2) and 91(2)(d).

189 von Lewinski, above n 34, at 41. 
This article shares the ideals of rewarding authors and valuing their creative endeavours. However, these ideals are not served by the schemes explored here, and it would be undesirable to adopt either option in New Zealand. No single reform is likely to solve what has proven to be a complex and interwoven problem. As to adopting a re-evaluation mechanism, caution is recommended. 
